\title{
Dampak Faktor Usia dan Paritas Terhadap Prevalensi Ketuban Pecah Dini Ibu pada Masa Bersalin
}

\author{
Yetty Wilda \\ Poltekkes Kemenkes Surabaya; yetiregina@gmail.com \\ Suparji \\ Poltekkes Kemenkes Surabaya; suparjibrisa@yahoo.co.id (koresponden)
}

\begin{abstract}
The most crucial problem due to pregnancy complications is the occurrence of premature rupture of membranes (PRM). Premature rupture of membranes is a difficult part in pregnancy and childbirth that has an effect on increasing meternal-perinatal morbidity and death. The purpose of this study was to determine the determinants of age and parity affect the incidence of PRM. This research was a kind of analytic observation research with case control design. The study population of all women in Widodo Hospital was 1348 women, the sample of PRM maternity cases with a sample of 30 respondents. Control sample of maternal mothers with a total of 30 respondents. The sampling technique was a simple random sampling method. The independent variable were age and parity, while the dependent variable was PRM. Data collection used a checklist in the form of secondary data. To analyze the data using the Logistic Regression Test with a significance level of 0.05. The results showed that most mothers with age $<20$-> 35 years $(79.3 \%)$ and $p$ value $=0.004$. OR value of age variable was 7.020 , it could be concluded that age had a 7 times greater risk of causing PRM. Multigravida parity (72.2\%) and $p=$ 0.010. The OR value of the parity variable was 6.481, it could be concluded that parity had a 6 times greater risk of causing PRM. Conclusion: there is an influence of age and parity factors on the incidence of PRM. Pregnant women must know the signs and risk factors for PRM so that pregnant women take better care of their pregnancy.
\end{abstract}

Keywords: age; parity; premature rupture of membranes

\begin{abstract}
ABSTRAK
Masalah yang paling krusial akibat komplikasi kehamilan adalah kejadian ketuban pecah dini (KPD). Ketuban pecah dini merupakan bagian penyulit dalam kehamilan dan persalinan yang berpengaruh dalam meningkatkan kesakitan dan kematian meternal-perinatal. Tujuan penelitian ini adalah untuk mengetahui determinan usia dan paritas berpengaruh terhadap kejadian KPD. Penelitian ini merupakan jenis penelitian observasi analitik dengan rancangan case control. Populasi penelitian semua ibu bersalin di RS Widodo sebesar 1348 ibu bersalin ,Sampel kasus ibu bersalin KPD dengan jumlah sampel 30 responden. Sampel kontrol ibu bersalin dengan jumlah 30 responden. Teknik sampling dengan metode simple random sampling. Variabel independen adalah usia dan paritas, sedangkan variabel dependen adalah jejadian KPD. Pengumpulan data menggunakan checklist berupa data sekunder. Untuk menganalisis data menggunakan Uji Regresi Logistik dengan taraf nyata 0,05.Hasil penelitian menunjukkan bahwa sebagian besar ibu dengan usia <20->35 tahun $(79,3 \%)$ dan nilai $p=0,004$. Nilai OR variabel usia yaitu 7,020, dapat disimpulkan usia mempunyai risiko 7 kali lebih besar menyebabkan KPD. Paritas Multigravida (72,2\%) dan nilai $\mathrm{p}=0,010$. Nilai OR variabel paritas yaitu 6,481, dapat disimpulkan paritas mempunyai risiko 6 kali lebih besar menyebabkan KPD. Kesimpulan: ada pengaruh faktor usia dan paritas terhadap kejadian KPD. Ibu hamil harus mengetahui tanda dan faktor risiko terjadinya KPD sehingga ibu hamil lebih menjaga kehamilannya.
\end{abstract}

Kata kunci: usia; paritas; ketuban pecah dini 


\section{PENDAHULUAN}

\section{Latar Belakang}

Ketuban pecah dini ialah pecahnya ketuban sebelum terdapat tanda-tanda persalinan dan ditunggu 1 jam belum terjadi inpartu ${ }^{(1)}$. Ketuban pecah dini merupakan salah satu penyulit dalam kehamilan dan persalinan yang berperan dalam meningkatkan kesakitan dan kematian meternal-perinatal yang dapat disebabkan oleh adanya infeksi, yaitu dimana selaput ketuban yang menjadi penghalang masuknya kuman penyebab infeksi sudah tidak ada sehingga dapat membahayakan bagi ibu dan janinnya ${ }^{(1,4,5,6)}$.

Menurut Kemenkes RI dalam program Sustainable Development Goals (SDGs) bahwa target sistem kesehatan nasional yaitu pada goals ke 3 menerangkan bahwa pada 2030, mengurangi angka kematian ibu hingga dibawah 70 per 100.000 kelahiran hidup ${ }^{(2,3)}$. Hasil Survey Demografi Kesehatan Indonesia (SDKI) Angka Kematian Ibu pada tahun 2012 menunjukan Angka Kematian Ibu sebesar 359 per 100.000 kelahiran hidup. Jumlah kematian ibu di Provinsi Jawa Timur mengalami peningkatan. Tahun 2016, target AKI sebesar 305 per $100.000 \mathrm{KH}$. Pada tahun 2016, AKI Provinsi Jawa Timur mengalami peningkatan dibandingkan tahun 2015 yang mencapai 89,6 per $100.000 \mathrm{KH}$. Ada beberapa penyebab kematian ibu, salah satunya adalah infeksi $4,87 \%{ }^{(3)}$. Berdasarkan studi pendahuluan di RS Widodo Ngawi tahun 2018 pada bulan Januari-Desember tahun 2018, dari 1348 ibu yang bersalin, ibu yang mengalami KPD sebanyak 169 (12,53\%) orang ${ }^{(3)}$.Penelitian yang dilaku kan oleh Linda Fitriani disimpulkan bahwa terdapat hubungan antara paritas dengan kejadian ketuban pecah dini pada ibu hamil ${ }^{(5,7,8)}$.

Faktor yang menyebabkan ketuban pecah dini yaitu usia, paritas, kelainan letak, hidramnion dan gemeli. Usia untuk reproduksi bagi seseorang ibu antara umur 20-35 tahun, dibawah atau diatas usia tersebut angka meningkat risiko kehamilan dan persalinan. Paritas akan mempengaruhi terjadinya ketuban pecah dini ${ }^{(1,4,6)}$. Ibu yang telah melahirkan beberapa kali akan lebih berisiko mengalami ketuban pecah dini disebabkan vaskularisasi pada uterus mengalami gangguan yang menimbulkan jaringan ikat selaput ketuban mudah rapuh dan akhirnya pecah secara $\operatorname{spontan}^{(4,6)}$.

\section{Tujuan Penelitian}

Tujuan dalam penelitian ini adalah untuk mengetahui adakah pengaruh faktor usia dan paritas terhadap kejadian KPD di RS Widodo Ngawi.

\section{METODE}

Rancangan penelitian penelitian yang digunakan adalah penelitian kasus kontrol (case control study) Populasi penelitian ini adalah seluruh ibu bersalin sebanyak 1348 ibu bersalin. Sampel untuk kelompok kontrol ditentukan menurut ${ }^{(9)}$ perbandingan antara kelompok kasus dan kelompok kontrol yaitu 1:1. Jumlah sampel pada kelompok kontrol sebanyak $30 \mathrm{ibu}$ bersalin normal, pengambilan sampling menggukanan teknik Simple Random Sampling. Variabel bebas dalam penelitian yaitu usia dan paritas. Insrumen peneitian yang digunakan adalah instrumen cheklist. Analisis data mengunakan statistic deskriptip dan analitik (Logisik Linear) penyajian data dengan tektuler.

\section{HASIL}

\section{Hasil Analisis Tahap Pertama}

Pada tabel 1, hasil penelitian tentang kejadian KPD di lihat dari faktor usia dan parias menunjukkan bahwa kejadian KPD lebih banyak berasal dari ibu berusia <20 tahun atau >35 tahun, dan dari kelompok multigravida. Ini berbeda dengan riwayat dari ibu tidak dengan KPD yang berasal dari kelompok 20-35 tahun dan primigravida. 
Tabel 1. Distribusi proporsi kejadian KPD berdasarkan usia dan paritas

\begin{tabular}{|l|c|c|l|}
\hline \multirow{2}{*}{ Variabel } & \multicolumn{2}{|c|}{ Ketuban Pecah Dini } & \multirow{2}{*}{-value } \\
\cline { 2 - 3 } & KPD & Tidak KPD & \\
\hline Usia & & & 0,000 \\
$<20$ dan $>35$ tahun & $23(76,7 \%)$ & $6(20,0 \%)$ & \\
$20-35$ tahun & $7(23,3 \%)$ & $24(80,0 \%)$ & \\
Total & $30(100,0 \%)$ & $30(100,0 \%)$ & \\
& & & \\
Paritas & $26(86,7 \%)$ & $10(33,3 \%)$ & \\
Multigravida & $4(13,3 \%)$ & $20(66,7 \%)$ & \\
Primigravida & $30(100,0 \%)$ & $30(100,0 \%)$ & \\
Total & & & \\
& & & \\
& & & \\
\hline
\end{tabular}

Untuk korelasi antara usia dan paritas dengan kejadian KPD menggunakan uji Chi Square didapatkan $p$ value masing-masing adalah 0,000 $(<0,25)$, sehingga memenuhi syarat untuk dilakukan uji Regresi Logistik. Beda risiko usia terhadap KPD adalah 0,586 dan beda risiko paritas terhadap KPD adalah 0,555. Sedangkan risiko relatif usia terhadap KPD adalah 3,83 dan risiko relatif paritas terhadap KPD adalah 4,32.

\section{Hasil Analisis Tahap Kedua}

Berdasarkan hasil uji regresi logistik dari kedua variabel didapatkan nilai signifikasi atau $p=0,00(p$ $<0,05)$, maka $\mathrm{H}_{0}$ ditolak berarti terdapat hubungan antara usia dengan kejadian KPD, juga terdapat hubungan antara paritas dengan kejadian KPD. Pada analisis logistik dari variabel in the equation, faktor yang paling dominan dengan kejadian KPD pada ibu bersalin berturut-turut meliputi usia $(7,020)$ dan paritas $(6,481)$.

\section{PEMBAHASAN}

\section{Hubungan Usia dengan Kejadian KPD pada Ibu Bersalin}

Hasil penelitian menunjukkan bahwa ada pengaruh antara usia terhadap kejadian KPD. KPD banyak terjadi pada usia $<20$ dan $>35$ tahun. Besar risiko usia 7 kali untuk terjadi KPD, sehingga usia memberikan risiko 7 kali lebih besar untuk terjadinya KPD.

Kehamilan yang terjadi pada usia $<20$ tahun atau terlalu muda sering menyebabkan komplikasi/ penyulit bagi ibu dan janin, hal ini disebabkan belum matangnya alat reproduksi untuk hamil, dimana rahim belum bisa menahan kehamilan dengan baik, selaput ketuban belum matang dan mudah mengalami robekan sehingga dapat menyebabkan terjadinya ketuban pecah dini. Sedangkan pada usia yang terlalu tua atau > 35 tahun memiliki risiko kesehatan bagi ibu dan bayinya ${ }^{(6)}$. Keadaan ini terjadi karena otot-otot dasar panggul tidak elastis lagi sehingga mudah terjadi penyulit kehamilan dan persalinan. Salah satunya adalah perut ibu yang menggantung dan serviks mudah berdilatasi sehingga dapat menyebabkan pembukaan serviks terlalu dini yangmenyebabkan terjadinya ketuban pecah dini.

Penelitian ini didukung dengan penelitian N.L Safitri \& Ambarwati (2016) di RS Islam Sunan Kudus menunjukkan ada hubungan antara umur ibu dengan kejadian ketuban pecah dini ${ }^{(8,10,11)}$. Penelitian Susilowati dan Astuti (2010 yang melaporkan bahwa usia kurang dari 20 tahun atau lebih dari 35 tahun merupakan 
golongan risiko tinggi untuk melahirkan. Usia berkaitan dengan peningkatan atau penurunan fungsi tubuh sehingga mempengaruhi status kesehatan. Usia $<20$ dan $>35$ tahun berisiko lebih besar untuk terjadi KPD. Untuk itu disarankan kepada masyarakat khususnya ibu hamil dalam usia berisiko untuk melakukan pemeriksaan antenatal yang teratur dan bermutu serta teliti dan mengenali tanda-tanda sedini mungkin sehingga diberikan pengobatan yang sesuai supaya tidak terjadi komplikasi baik ibu dan janinnya ${ }^{(10,12)}$.

\section{Hubungan Paritas dengan Kejadian KPD pada Ibu Bersalin}

Hasil penelitian menunjukkan bahwa ada pengaruh antara paritas terhadap kejadian KPD. KPD banyak terjadi pada paritas multigravida. Besar risiko paritas multigravida 6 kali untuk terjadi KPD, sehingga paritas multigravida memberikan risiko 7 kali lebih besar untuk terjadinya KPD. Ibu yang sudah melahirkan beberapa kali lebih beresiko mengalami KPD, oleh karena vaskularisasi pada uterus mengalami gangguan yang mengakibatkan jaringan ikat selaput ketuban mudah rapuh dan akhirnya pecah spontan ${ }^{(4,6)}$.

Terjadinya ketuban pecah dini juga karena terjadi trauma langsung pada perut ibu, mungkin karena kelainan letak pada rahim dan grande multipara atau kehamilan lebih dari lima kali. Penyebab ketuban pecah dini dalam paritas salah satunya ialah multiparitas. Multipara lebih besar memungkinkan terjadinya infeksi karena adanya proses pembukaan serviks lebih cepat dibandingkan primipara, sehingga dapat mengakibatkan pecahnya ketuban lebih dini. Penelitian yang dilakukan oleh Linda Fitriani di RSUD Dr. Wahidin menyimpulkan bahwa terdapat hubungan antara paritas dengan kejadian ketuban pecah dini pada ibu hamil ${ }^{(8,10,12)}$.

Penelitian ini didukung oleh Heny Hastuti 2016, bahwa ibu dengan paritas sampai atau lebih dari 4 mempunyai kemungkinan 9,94 kali lebih besar mengalami kejadian KPD dibandingkan dengan ibu dengan paritas kurang dari $4^{(11,12}$. Paritas multigravida memiliki risiko lebih tinggi untuk terjadi KPD. Oleh karena itu, seorang ibu multigravida sebaiknya mengikuti konseling dengan petugas pelayanan keehatan, sehingga dapat mengetahui faktor risiko terjadinya $\operatorname{KPD}^{(10,11,12)}$.

\section{KESIMPULAN}

Hasil penelitian menunjukkan bahwa ada hubungan antara usia dengan kejadian KPD, kelompok usia $<20$ dan $>35$ tahun mempunyai risiko 7 kali lebih besar menyebabkan terjadinya KPD. Kesimpulan lain bahwa ada hubungan antara paritas dengan kejadian KPD pada ibu bersalin. Paritas mempunyai risiko 6 kali lebih besar menyebabkan KPD.

Disarankan perlu peningkatan upaya pelayanan kesehatan ibu hamil, khususnya dalam mendeteksi risiko kehamilan, melalui pelayanan ANC.

\section{DAFTAR PUSTAKA}

1. Cunningham FG. Obstetri Williams. Jakarta: EGC; 2006.

2. Kemenkes RI. Asuhan Persalinan Normal. Jakarta: JHPIEGO; 2013.

3. Dinas Kesehatan Provinsi Jawa Timur. Profil Kesehatan Provinsi Jawa Timur,Surabaya: Dinkes Prov Jatim; 2017.

4. Mustika D. Asuhan Kebidanan Patologi. Yogyakarta: Nuha Medika; 2013.

5. Rachmawati E. Hubungan Besar Janin dan Paritas Dengan Tindakan Proses Persalinan Normal Pada Ibu Bersalin. Semarang: Abdi Husada; 2008.

6. Fadlan. Asuhan Kebidanan Patologi. Jakarta: Salemba Medika; 2011.

7. Fitriani L. Paritas Dengan Kejadian Ketuban Pecah Dini pada Ibu Hamil di RSUD Dr. Wahidin Sudirohusodo Kota Mojokerto. Mojokerto; 2015.

8. Fatikah. Hubungan Antara Kejadian Ketuban Pecah Dini Dengan Paritas Di Rumah Sakit Umum Daerah Dr Soedarso Pontianak. Pontianak: Jurusan Kebidanan Poltekkes Kemenkes Pontianak; 2015.

9. Hastono SP. Modul Analisis Data. Fakultas Kesehatan Masyarakat. Jakarta: Universitas Indonesia; 2007.

10. Hastuti H. Analisis Faktor Risiko Ketuban Pecah Dini di Rumah Sakit Umum Bahteramas. Kendari: Fakultas Kedokteran UHO; 2016. 
11. Hidayat AA. Metode Penelitian Keperawatan dan Teknis Analisis Data. Jakarta: Salemba Medika; 2014.

12. Arie H. Analisa Masalah Ketuban Pecah Dini Terhadap Paritas di RS PKU Muhammadiyah Surakarta. Surakarta: Universitas Muhammadiyah Surakarta; 2013. 